\title{
EVALUATION OF FIRE LOOKOUT TOWERS USING GIS-BASED SPATIAL VISIBILITY AND SUITABILITY ANALYZES
}

\author{
PROCJENA TORNJEVA ZA NADZOR POŽARA POMOĆU \\ ANALIZE PROSTORNE VIDLJIVOSTI I PRIKLADNOSTI \\ POTPOMOGNUTE GIS-OM
}

\author{
Abdullah E. AKAY1* ${ }^{*}$ Michael WING², Halit BÜYÜKSAKALLI³, Salih MALKOÇOǦLU³
}

\begin{abstract}
SUMMIRY
Effective forest fire fighting involves alerting firefighting teams immediately in the case of a fire so that teams can promptly arrive the fire scene. The most effective way for an early detection of forest fires is monitoring of forest lands from fire lookout towers. Especially in fire sensitive forest lands, towers should be systematically located in such a way that fire lookout personnel can monitor the largest amount of forest land as possible. In this study, the visibility capabilities of lookout towers located in Köyceğiz Forest Enterprise Directorate (FED)in the city of Muğla in Turkey were evaluated by using Geographical Information System (GIS) based visibility and suitability analysis. The results of visibility analysis indicated that $77.12 \%$ of forest land were visible from the current towers. To extend the proportion of visible forest lands, locations of additional lookout towers were evaluated using spatial visibility and suitability analysis in which the tower locations were examined by considering specific criteria (i.e. distance to roads, elevation, ground slope, topographic features). Suitability analysis results identified five new towers in addition to current towers in the study area. The results indicated that visible forest lands increased to $81.47 \%$ by locating new towers, and increase of almost $4.35 \%$. In addition, over half of the forests became visible by at least two towers when including five towers suggested by suitability analysis. The GIS-based method developed in this study can assist fire managers to determine the optimal locations for fire lookout towers for effective fire management activities.
\end{abstract}

KEY WORDS: Forest fires, Fire monitoring, Visibility and Suitability analysis, Köyceğiz

\section{INTRODUCTION}

\section{UVOD}

Forest fires have been known since time immemorial as a primary factor endangering the sustainability of forest resources. Despite today's technological advancements, the forest fire occurrence has increased across the world and especially in the Mediterranean countries (i.e. Greece, Italy,
Spain, Turkey, etc.) due to climatic conditions and vegetation characteristics (Demir et al., 2009). Forest fires are frequently caused by human factors correlated with increased population around forest land and public demand for forest resources.

In Turkey, about 13 million ha of forest land is considered to be highly prone to forest fires and approximately 8

\footnotetext{
${ }^{1}$ Prof. Dr. Abdulah E. Akay, Bursa Technical University, Faculty of Forestry, 16310 Yıldırım, Bursa, Turkey, e-mail: abdulah.akay@btu.edu.tr

${ }^{2}$ Assoc. Prof. Dr. Michael Wing, Oregon State University, College of Forestry, Corvallis, 97331 Oregon, USA

${ }^{3}$ Msc. Halit Büyüksakalh, Msc. Salih Malkocoglu, Muğla Sıtkı Koçman University, Köyceǧiz Vocational School, Köyceǧiz, Muǧla, Turkey
} 
million ha of forest land is classified as first degree fire sensitive forests (GDF, 2012). The average number of forest fires is over 2000 per year and about 12000 ha of forest land is impacted after fires (Sivrikaya et al., 2014). According to fire statistics between 1973 and 2009, about 172,000 ha of forest land has been destroyed as a result of 174 large forest fires (i.e. $>300$ ha of burned area). The highest number of large fires occurs near the city of Muğla, followed by Balıkesir, Antalya, İzmir, and Adana (Ertuğrul and Varol, 2016).

To prevent large forest fires and forest fires in general, the firefighting team should arrive at the fire scene as quickly as possible so as to increase the probability of controlling the forest fire (Akay et al., 2012). In order to minimize damages caused by the forest fires and the cost of fire extinguishing activities, it is important to detect forest fires as early as possible and inform firefighting teams immediately for fire control (Mascaraque et al., 2007). The most effective way for an early detection of forest fires is by systematically locating fire lookout towers and monitoring fire sensitive forestlands that are visible from these towers (Millan-Garcia et al., 2012; Yuan et al., 2015).

During the fire season in Turkey, the General Directorate of Forestry establishes fire lookout towers where fire watch personnel monitor forests continually and maintain communication with firefighting teams (Gülci et al., 2016). Fire lookout towers are located at the highest points that are generally on ridges where large forestlands can be seen by fire watch personnel. Thus, fire lookout towers should be carefully located in such a way that ensures fire lookout personnel are able to monitor as much forest land as possible in the region.

In recent decades, Geographical Information System (GIS) techniques have been used in monitoring forest fires, generation of fire risk maps, and in development of firefighting strategies (Vipin, 2012; Sivrikaya et al., 2014). In determination of the areas that are visible from specified sets of locations, viewshed analysis has been effectively used in GIS technologies based on a profile extraction method (Singh et al., 2014). In a study conducted by Akbulak and Özdemir (2008), visibility analysis was implemented to investigate forest lands that are visible and not visible from fire lookout towers in the Gallipoli Peninsula in Turkey. They reported that most of the area consisted of coniferous forest that cannot be seen by the current lookout towers. In a similar study, GIS and remote sensing techniques were used to evaluate suitability of fire lookout towers considering fire risk zones (Korale et al., 2009). Pompa-García et al. (2010) suggested that visibility analysis with a digital elevation model (DEM) should be combined with a vegetation cover map. They found that visibility effectiveness of the current lookout towers was about $43 \%$ which indicated that more than half of the forest land in the study area was not visible by the lookout towers. In a recent study, GIS techniques were implemented to evaluate visibility capabilities of fire lookout towers in a study area located in north of Turkey with Mediterranean-like climate (Kucuk et al., 2017). The authors suggested that additional fire lookout towers were needed in the area since some of the current lookout towers were not functioning properly. In another study, visibility of forest lands was examined by fire lookout towers in the city of Dalaman in Turkey (Göltaş et al., 2017). As a result of the study, it was found that only $47 \%$ of forest lands could be monitored by fire lookout towers.

In cases where the locations of the lookout towers are not suitable to monitor forest lands in a specific area, alternative lookout towers can be considered to improve the percentages of visible forest lands. In the consideration of suitable locations for new towers, it is important to evaluate defined criteria about the candidate points before visibility analysis. Such complex problems involving determination of optimal site locations can be solved by using a GIS based suitability analysis approach. Suitability analysis can be used to generate new data sets from existing data, reclassify data to detect areas with high suitability, and combine the data into one final result of optimal suitability (Koikai, 2008). There are various examples of suitability analysis in the field of forestry (Gülci and Akay, 2015; Quinta-Nova et al., 2017), however, there are a limited number of studies that attempted to search for potential fire lookout towers based on specific factors. These factors may include proximity to road network for easy access, minimum elevation to be able to see large forest lands, low ground slope for proper construction, and topographical form of the point (i.e. ridges) to ensure $360^{\circ}$ angle of vision (Harvey, 2015).

In this study, the forested lands that can be seen by the lookout towers in Köyceğiz FED of Muğla Forestry Regional Directorate were examined using visibility analysis in ArcGIS 10.4 software. Besides, locations for additional towers were determined by using GIS based suitability analysis in order to extend the visible forest lands by the lookout towers. Therefore, the distinct contribution of this approach is that not only the visibility capabilities of new towers were investigated but also suitability of the tower locations was examined in Mediterranean region forests that are highly sensitive to wild fires.

\section{MATERIAL AND METHOD MATERIJALI I METODA}

\section{Study Area - Područje istraživanja}

This study was conducted in the border of Köyceğiz FED in the city of Muğla within the Mediterranean region of Turkey. The Köyceğiz FED is located at $36^{\circ} 46^{\prime} 53^{\prime \prime}-$ 


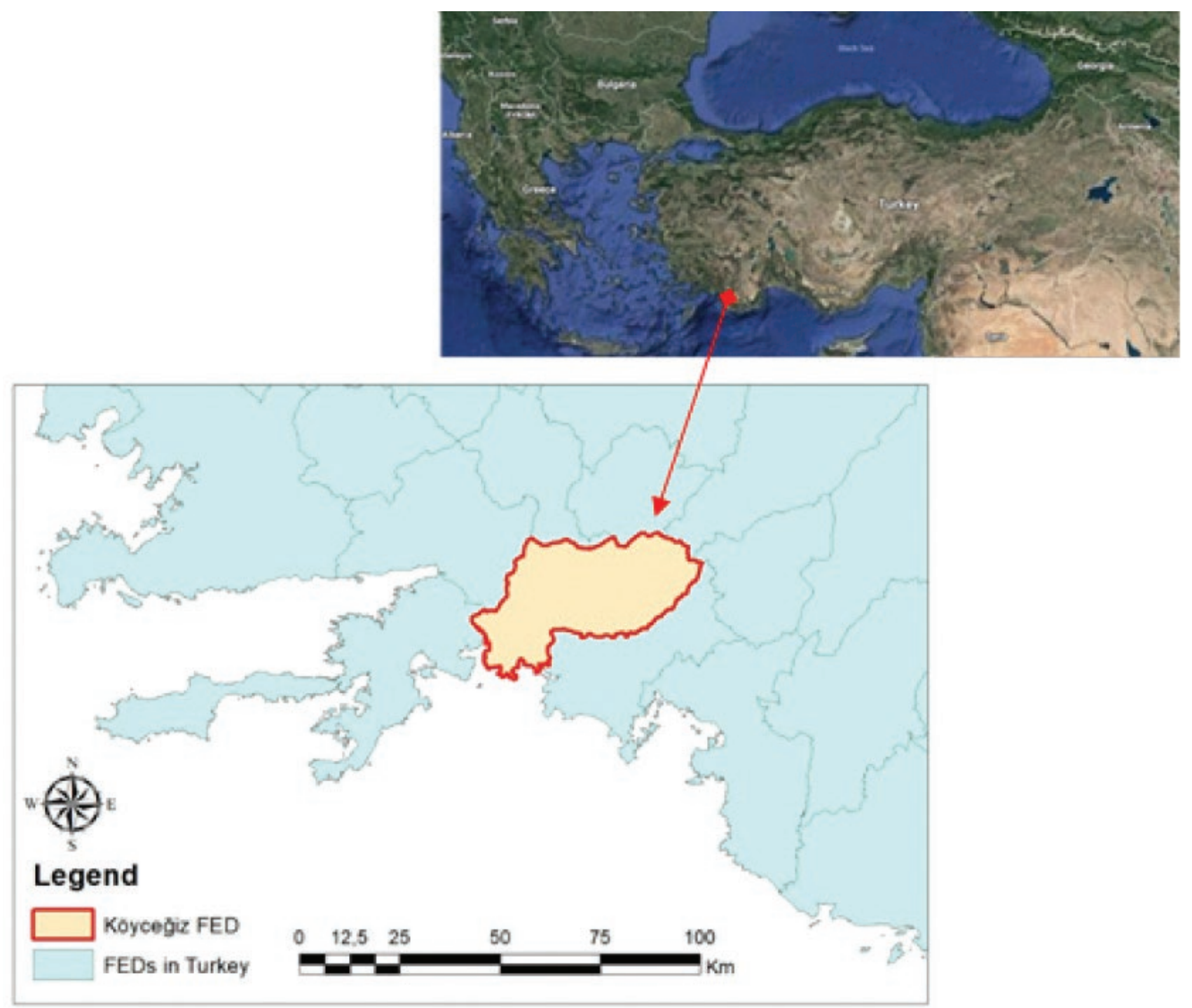

Figure 1. Study area

Slika 1. Područje istraživanja

$37^{\circ} 06^{\prime} 30^{\prime \prime}$ north latitude and $28^{\circ} 25^{\prime} 00^{\prime \prime}-29^{\circ} 04^{\prime} 50^{\prime \prime}$ east longitude. Total area of the FED is 118,484 ha where there are six Forest Enterprise Chiefs (FECs) including Ağla, Akköprü, Beyobası, Karaçam, Köyceğiz, and Sultaniye FECs (Figure 1).

According to the forest management plan data of Köyceğiz FED, total forest land in the region is mostly $(65 \%)$ covered with coniferous forests (GDF, 2012). About $94 \%$ of the coniferous forests consist of pine species (Pinus brutia Ten. and Pinus nigra) while $1 \%$ is covered with cedar (Cedrus libani), and rest of the area is covered with other coniferous species. According to the fire sensitivity classification provided by GDF, forest lands in the study area are sensitive to forest fire at the first degree (Akay et al., 2010). Particularly, Brutian pine (Pinus brutia Ten.) stands are highly prone to forest fire which increases the risk of forest fire in the region. In addition, the study area is located in a region that is very rich in terms of biodiversity, natural lakes and seashores, historical and cultural assets, and special environmental protection zones. Thus, forest fires are not only threatening the forest resources but also many desirable natural resources within the borders of Köyceğiz FED.

The average elevation of Köyceğiz FED is $583 \mathrm{~m}$ with an average slope of 32\%. The area has Mediterranean-like climatic conditions where there is rather high temperatures in the summer and fairly low in the winter. The average wind speed is 1.2 meters per second. June, July, August, and September are the hottest months of the year while January is the coldest in the area. Based on the meteorological data obtained from Köyceğiz FED, the lowest and highest temperatures are $-7^{\circ} \mathrm{C}$ and $43^{\circ} \mathrm{C}$, respectively, with an overall annual average temperature of $18.3^{\circ} \mathrm{C}(\mathrm{GDF} 2016)$. In the region, average relative humidity is $69 \%$ and the average annual precipitation is $1151.2 \mathrm{~mm}$. 
Table 1. Distribution of forest resources and fire information in Köyceğiz FED (1999-2016)

Tablica 1. Raspored šumskih izvora i obavijesti o požaru u šumariji Köyceǧiz (1999. -2016.)

\begin{tabular}{lccc} 
FECs & $\begin{array}{c}\text { Forest Land (ha) } \\
\text { Šmsko područje } \\
\text { (ha) }\end{array}$ & $\begin{array}{c}\text { Number of Fires } \\
\text { Broj požara }\end{array}$ & $\begin{array}{c}\text { Burned Area (ha) } \\
\text { zgorena površina } \\
\text { (ha) }\end{array}$ \\
\hline Ağla & 16908 & 30 & 3.81 \\
Akköprü & 10200 & 50 & 138.89 \\
Beyobası & 15431 & 87 & 84.78 \\
Karaçam & 18736 & 209 & 161.53 \\
Köyceğiz & 11350 & 51 & 109.25 \\
Sultaniye & 25811 & 42 & 18.93 \\
Total & 98436 & 469 & 517.20 \\
Ukupno & & &
\end{tabular}

Table 2. Information about fire lookout towers

Tablica 2. Obavijesti o tornjevima za nadzor požara

\begin{tabular}{lccc} 
Lookout Towers & \multicolumn{2}{c}{$\begin{array}{c}\text { UTM Coordinates } \\
\text { UTM koordinate }\end{array}$} & $\begin{array}{c}\text { Elevation }(\mathrm{m}) \\
\text { Visina }(\mathrm{m})\end{array}$ \\
Tornjevi za nadzor & $\mathrm{X}$ & $\mathrm{Y}$ & \\
Kandil & 634852 & 4085818 & 860 \\
Ölemez & 641441 & 4081066 & 920 \\
Çiçekbaba & 660366 & 4100557 & 2020 \\
Buyancık & 669418 & 4092572 & 1100 \\
Kepez & 676921 & 4101706 & 1400
\end{tabular}

According to the forest fire statistics between 1999 and 2016 , about $38 \%$ of the fires are caused by lightning, $36 \%$ by intention, $19 \%$ by negligence and carelessness, $6 \%$ by unknown reasons, and $1 \%$ by electricity transformer. Within this 17-year period,517.20 ha of forest land was damaged as a result of 468 forest fires recorded in the study area (Table 1) (GDF, 2016). There are five fire lookout towers in Köyceğiz FED including Kandil, Ölemez, Çiçekbaba, Buyancik, and Kepez. The location and the elevation information of the current fire lookout towers were obtained from Köyceğiz FED (Table 2).

\section{Generating GIS Database - Stvaranje baze podataka GIS-a}

The success of the visibility analysis of lookout towers mostly depends on an accurate Digital Terrain Model (DTM). In this study, a DTM of Köyceğiz FED was generated based on ASTER satellite imagery (2011) with a 15 $\mathrm{mx} 15 \mathrm{~m}$ spatial resolution. ASTER is a high resolution imaging instrument that produces remote sensing images in 14 different wavelengths. In addition, ASTER is widely used in the production of DTMs because it is easily accessible and able to produce high resolution stereo images (Bignone and Umakawa, 2008; Trisakti and Julzarika, 2011). Based on the DTM data, the slope map of FED was generated using "Raster Surface" tool in ArcGIS 10.4.

In order to evaluate forest lands that can be observed from the lookout towers, a digital layer representing the forest land is necessary. Using the ArcGIS 10.4 program, the digital data layer of forest land in the study area was generated based on a land use type map (1:25000) which was obtained from Köyceğiz FED. A boundary data layer was used

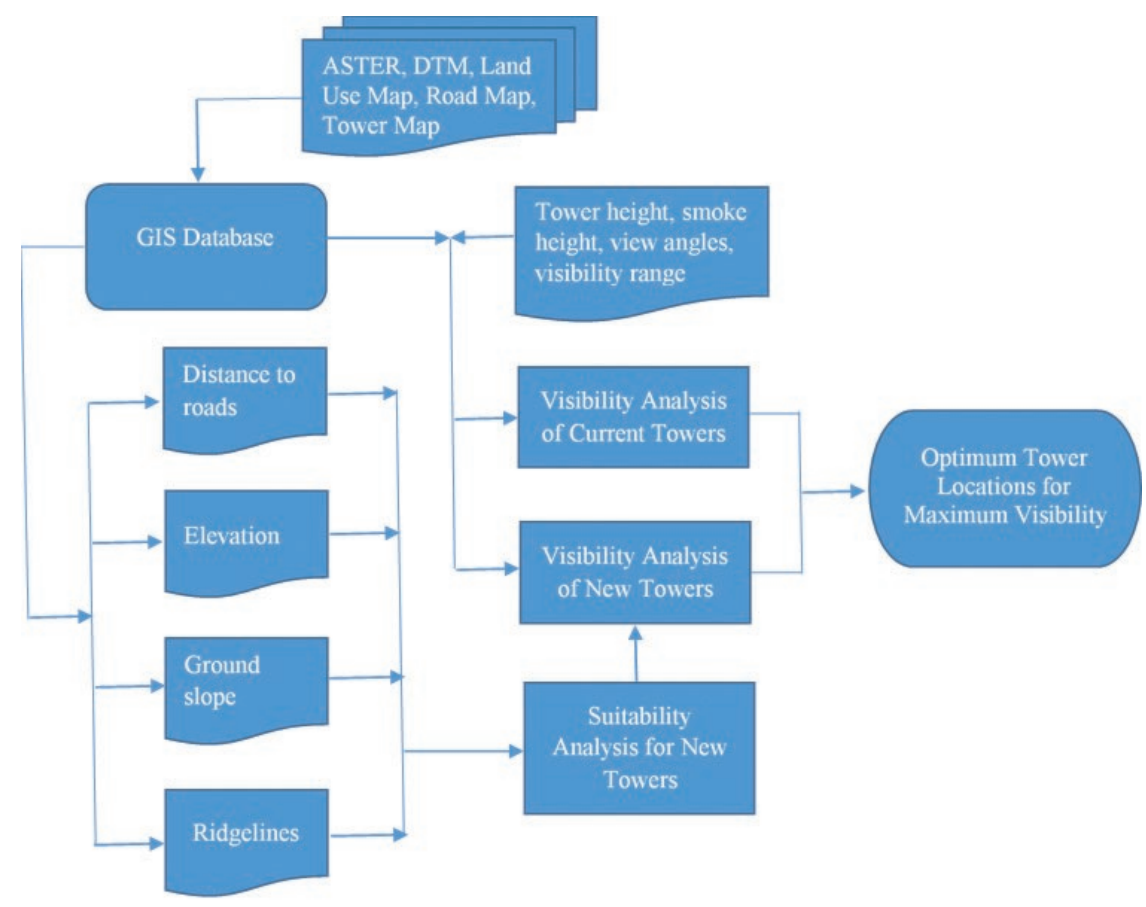

Figure 2. The flowchart of the methodology

Slika 2. Dijagram tijeka metodologije 
to extract DTM and slope layers specific to the Köyceğiz FED.

The digital data layer indicating the locations of current fire lookout towers in the study area was generated by using provided UTM coordinates (Table 2). The road layer of the study area, obtained from Köyceğiz FED, was also included into the GIS database to be used in the process of searching for possible new lookout towers.

\section{Visibility Analysis of Current Towers - Analiza vidljivosti sadašnjih tornjeva}

Visibility analysis measures the visibility of viewing capability of a certain location to see the surrounding area. In this study, the visibility performance of five fire lookout towers was analyzed by using the "Observer Points" method in ArcGIS 10.4 program. Figure 2 indicates the flowchart of the methodology. The "Observer Points" method requires data inputs in the attribute table of fire lookout towers. These required inputs include elevation, tower height, smoke visibility height, horizontal view angle, visibility range, and vertical view angle. Table 3 indicates the required data to be entered in the attribute table of the lookout towers layer.

The elevation data from Table 2 were included in the attribute table of the towers. The height of each lookout tower was $10 \mathrm{~m}$ and smoke visibility height was estimated as 100 $\mathrm{m}$ to see smokes rising from the ground as well as flames on the ground during a forest fire. In order to observe all of the forested areas around the lookout towers, angle of vision and angle of view was set to 360 degree and +/-90 degree, respectively.

In this study, the visibility ranges of fire lookout towers were set from $10 \mathrm{~km}$ to $20 \mathrm{~km}$ based on the information obtained from Köyceğiz FED. The visibility range of $10 \mathrm{~km}$ scanning radius is widely preferred distance for rough terrain for detecting the smoke under optimal weather conditions (Kucuk et al., 2017). However, different scanning radiuses have been used in other locations. In the USA, scanning radiuses ranging from 13 to $32 \mathrm{~km}$ have been used while a radius of $24 \mathrm{~km}$ is typical in a large part of western
USA. In the southern and southeaster US, where visibility is poorer due to humidity, a 10 to $13 \mathrm{~km}$ radius is most often used (Davis, 1959).

After inputting the required data in the attribute table of fire lookout towers, the "Observer Points" method in the "Spatial Analyst" tools was implemented. This identified the portion of forestlands that were visible and nonvisible from the fire lookout towers in the study area. In addition, for all forest lands that were determined to be visible, visibility was categorized as to whether areas could be observed by one, two, three, four, or five towers.

\section{Suitability Analysis of New Towers - Analiza prikladnosti novih tornjeva}

After evaluating the visibility capabilities of current lookout towers, alternative towers were investigated to increase the total area of forest lands visible from the existing lookout towers. The appropriate locations for new towers must be determined not only based on their visibility capabilities but also the suitability of their potential locations. Suitability analysis using GIS techniques allows users to qualify, compare, and rank alternative sites based on a set of criteria. In this study, suitable locations for new lookout towers were searched by considering specified factors including distance to roads for accessibility, minimum elevation, low ground slope for easy construction, and topographical feature (i.e. ridges) to ensure a $360^{\circ}$ angle of vision for finished construction (Harvey, 2015).

In the first stage of the suitability analysis, the "Proximity" tool in ArcGIS 10.4 was used to delineate accessible areas near roadways (i.e. within the 100 meters) by generating buffer polygons around a spatial road network (Clark, 2005). Then, other factors (minimum elevation, maximum ground slope, and ridges) were addressed within the border of buffer polygons. The minimum elevation of potential towers was set to 500 meters for better visibility of the forest land in the study area. Thus, the areas that were equal to or more than 500 meters in elevation were extracted from the DTM of the forest land in the study area as a starting point for analysis.

Table 3. The required data to be entered in the attribute table of the lookout towers layer

Tablica 3. Podatci potrebni za unos u atributivnu tablicu koja sadrži sloj tornjeva za nadzor

\begin{tabular}{|c|c|c|c|c|c|c|}
\hline $\begin{array}{l}\text { Lookout Towers } \\
\text { Tornjevi za } \\
\text { nadzor }\end{array}$ & $\begin{array}{c}\text { Elevation (m) } \\
\text { Visina (m) }\end{array}$ & $\begin{array}{l}\text { Tower height }(\mathrm{m}) \\
\text { Visina tornja }(\mathrm{m})\end{array}$ & $\begin{array}{l}\text { Smoke visibility } \\
\text { height (m) } \\
\text { Visina vidljivosti } \\
\text { dima (m) }\end{array}$ & $\begin{array}{c}\text { Horizontal view } \\
\text { angle (degree) } \\
\text { Horizontalni kut } \\
\text { gledanja (stupnjevi) }\end{array}$ & $\begin{array}{l}\text { Visibility range (km) } \\
\text { Domet vidljivosti } \\
(\mathrm{km})\end{array}$ & $\begin{array}{c}\text { Vertical view angle } \\
\text { (degree) } \\
\text { Vertikalni kut } \\
\text { gledanja (stupnjevi) }\end{array}$ \\
\hline Kandil & 860 & 10 & 100 & 360 & 15 & $+/-90$ \\
\hline Ölemez & 920 & 10 & 100 & 360 & 10 & $+/-90$ \\
\hline Çiçekbaba & 2020 & 10 & 100 & 360 & 20 & $+/-90$ \\
\hline Buyancık & 1100 & 10 & 100 & 360 & 20 & $+/-90$ \\
\hline Kepez & 1400 & 10 & 100 & 360 & 20 & $+/-90$ \\
\hline
\end{tabular}


To minimize construction costs and maximize ground stability, it was decided to locate lookout towers on ground with less than $5 \%$ slope. In this stage, the slope map developed previously was used to create a spatial layer of forested lands meeting the less than $5 \%$ slope criteria. Then, the ridgelines in the study area were determined since the ridges are considered as the best locations for the fire lookout towers in order to maximize visibility range (Harvey, 2015). Based on the DTM of the study area, ridgelines were determined using the "Flow Direction" and "Flow Accumulation" functions under the "Hydrology" tool in ArcGIS 10.4 (i.e. Flow Accumulation $=0$ ). Then, the "Raster Calculator" function within the "Spatial Analyst" tools was used to generate a raster data layer consisting of suitable lookout tower locations based on the specified factors. This raster data layer was converted to a point type vector layer where each point represented an alternative new lookout tower location. The elevations of alternative towers were determined by extracting elevation information from the DTM. To increase the visibility from the towers, their heights were set to $15 \mathrm{~m}$ while visibility range was estimated as $25 \mathrm{~km}$ based on the field observations in the study area. The values of the other fields in the attribute table of tower layer were the same as the values of current lookout towers in Table 3 (Figure 3). Finally, the least number of fire lookout out towers covering the largest percentages of the study area were selected by running the "Observer Points" method in the Model Builder tool of ArcGIS 10.4. The forest lands that are visible and nonvisible from the selected new towers were identified and visible forest lands in the study area were classified according to the number of selected new towers that were in sight.

\section{RESULTS AND DISCUSSION REZULTATI I RASPRAVA}

\section{GIS Database - Baza podataka GIS-a}

The land use type database of the Köyceğiz FED indicated that there were five land use types including forest land,

Table 4. Distribution of land use types in the study area Tablica 4. Raspodjela načina korištenja zemljišta u području istraživanja

$\begin{array}{lc}\begin{array}{l}\text { Land use types } \\ \text { Načini korištenja zemljišta }\end{array} & \begin{array}{c}\text { Area (\%) } \\ \text { Površina (\%) }\end{array} \\ \begin{array}{l}\text { Forest land } \\ \text { Šumsko područje }\end{array} & 83.65 \\ \begin{array}{l}\text { Agriculture } \\ \text { Poljoprivreda }\end{array} & 8.70 \\ \text { Water } & \\ \text { Voda } & 5.04 \\ \text { Settlement } & \\ \text { Naselje } & 2.17 \\ \text { Sand dunes } & \\ \text { Pješčane dine } & 0.44 \\ \text { Total } \\ \text { Ukupno }\end{array}$

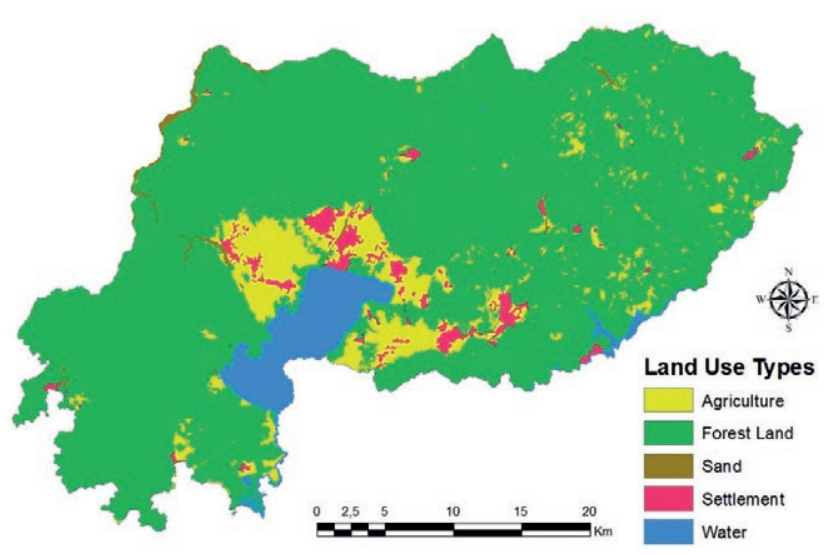

Figure 3. Study area land use

Slika 3. Korištenje zemljišta u području istraživanja

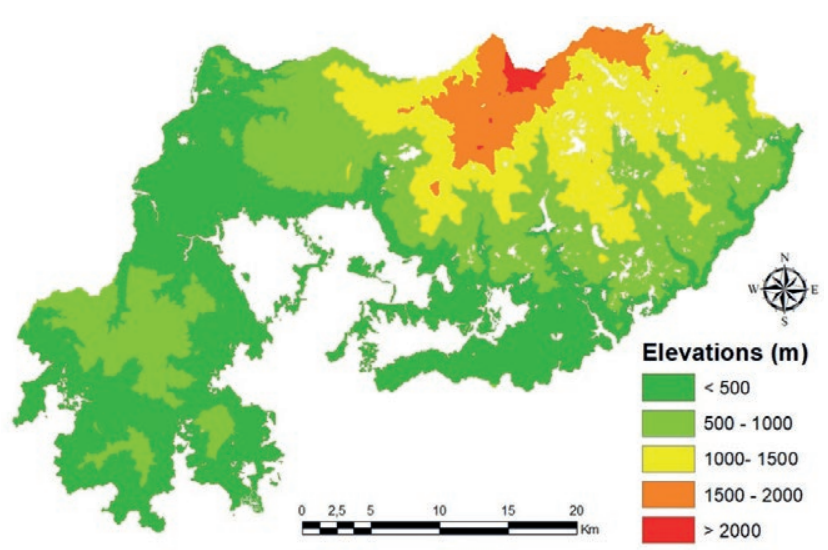

Figure 4. Study area terrain categories

Slika 4. Kategorije terena u području istraživanja

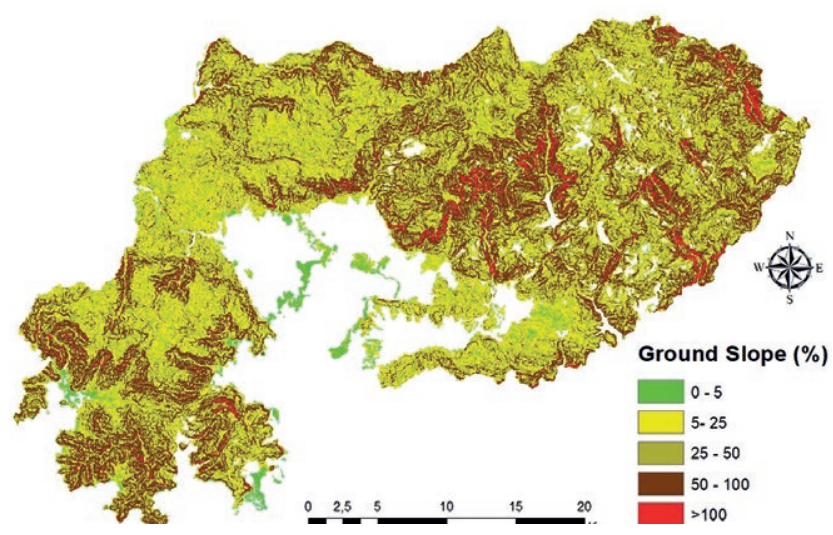

Figure 5. Study area ground slope categories

Slika 5. Kategorija nagiba terena u području istraživanja

agriculture, water, settlement, and sand dunes (Table 4). The largest land use type was forest land (83.65\%), followed by agricultural areas (8.70\%), and water bodies (5.04\%) (Figure 3). Forest land DTM data was extracted from the DTM of Köyceğiz FED by using the boundary of the forest land 
layer. The average elevation was found to be $679 \mathrm{~m}$ with a range between 479-2288 min the study area (Figure 4). The slope map of forest land that was generated based on the DTM indicated that the average slope was $38.33 \%$ in the forest lands (Figure 5).

\section{Assessment of Current Lookout Towers - Procjena sadašnjih tornjeva za nadzor požara}

The visibility capabilities of five current fire lookout towers were evaluated by using the "Observer Points" method in the ArcGIS 10.4 program. Forest lands that were within sight of the lookout towers in the study area are given in Figure 6. The results of the visibility analysis indicated that $77.12 \%$ of the forestland was visible from the current lookout towers. The forestlands observed by Kandil, Ölemez, Çiçekbaba, Buyancık, and Kepezfire lookout towers were $11745.62,35960.75,45774.25,22397.14$, and 16817.34 ha, respectively (Table 5).

It was found that the current lookout towers covering the largest forest land were the Çiçekbaba tower, followed by the Ölemez and Buyancik towers. Some parts of the forest lands were visible from more than one tower while some parts were visible only from a single tower (Figure 7). It was also found that forest land visible by only a single tower was

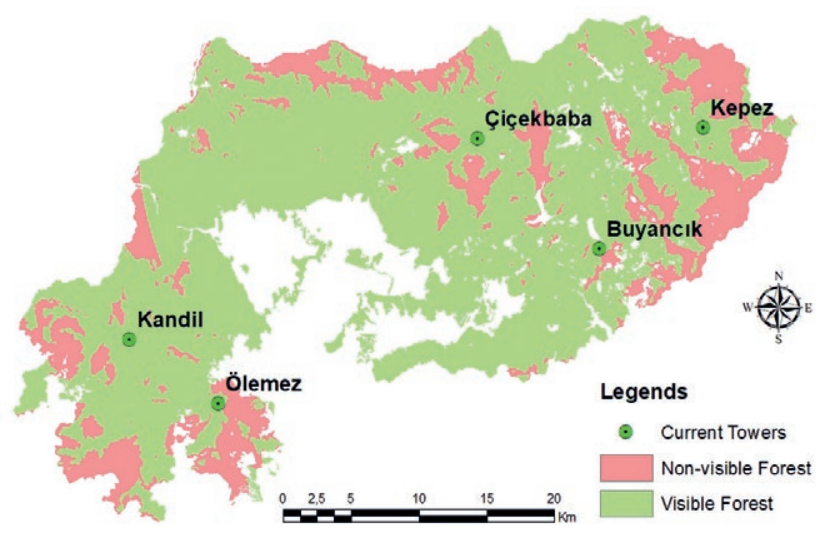

Figure 6. Forest land visibility from the current fire lookout towers Slika 6. Vidljivost šumskog područja sa sadašnjih tornjeva za nadzor požara

Table 5. Forest lands visible from the current fire lookout towers Tablica 5. Šumsko područje vidljivo sa sadašnjih tornjeva za nadzor požara

$\begin{array}{lcc}\begin{array}{l}\text { Lookout Towers } \\ \text { Tornjevi za nadzor }\end{array} & \begin{array}{c}\text { Total Area Visible from } \\ \text { Each Tower (\%) } \\ \text { Ukupna površina vidljiva } \\ \text { sa svakog tornja (\%) }\end{array} & \begin{array}{c}\text { Area Visible Only from a } \\ \text { Single Tower (\%) } \\ \text { Površina vidljiva samo s } \\ \text { jednog tornja (\%) }\end{array} \\ \text { Kandil } & 11.85 & 3.54 \\ \text { Ölemez } & 36.27 & 11.72 \\ \text { Çiçekbaba } & 48.27 & 14.57 \\ \text { Buyancık } & 27.07 & 2.52 \\ \text { Kepez } & 19.98 & 2.98\end{array}$

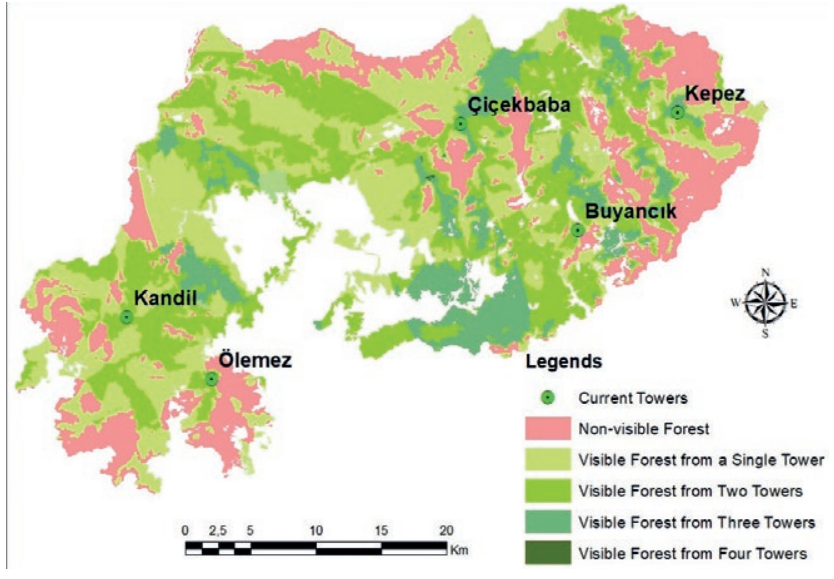

Figure 7. Forest lands visible by one or more current lookout towers Slika 7. Šumsko područje vidljivo s jednog ili više sadašnjih tornjeva za nadzor

35.33\%. The forest lands observed only by Kandil, Ölemez, Çiçekbaba, Buyancık or Kepez fire lookout tower was $3484.63,11536.70,14342.13,2480.59$, and 2933.39 ha, respectively. The areas visible by two, three, and four towers were $30.31 \%, 11.47 \%$, and $0.02 \%$, respectively. The results indicated that there was no forest land that could be seen by all of the lookout towers at the same time.

In a similar study, visibility analysis was used to evaluate three fire lookout towers located within the borders of Yayla FEC which is classified as a first degree fire sensitive area in western Turkey (Akay and Erdoğan, 2017). It was reported that $81 \%$ of the forest land in the FEC was visible from the lookout towers. In this study, the visibility analysis indicated that $77.12 \%$ of the forestland was visible by the lookout towers while it was not possible to monitor potential fires at the rest of the area from current locations of the lookout towers. By positioning new fire lookout towers, non-visible areas from the towers should be monitored especially in the forest lands with high fire risk (Kucuk et al., 2017). Thus, the locations for additional towers should be evaluated to increase the extent of visible forest lands from the lookout towers and to enhance monitoring of potential fires in the rest of the area.

\section{Assessment of New Lookout Towers - Procjena novih tornjeva za nadzor požara}

The visibility capabilities of new fire lookout towers were evaluated by implementing visibility analysis in GIS tools. Prior to the visibility analysis, however, potential locations of the towers should be assessed by using suitability analysis based on specified factors such as distance to roads, elevation, ground slope, and ridgelines. The road layer of the study area (Figure 8) indicated that the total length of the road network was $3835.75 \mathrm{~km}$ in which a large proportion of the total road being classified as forest road (dirt) (46.19\%), followed by gravel road (36.67\%), and asphalt 


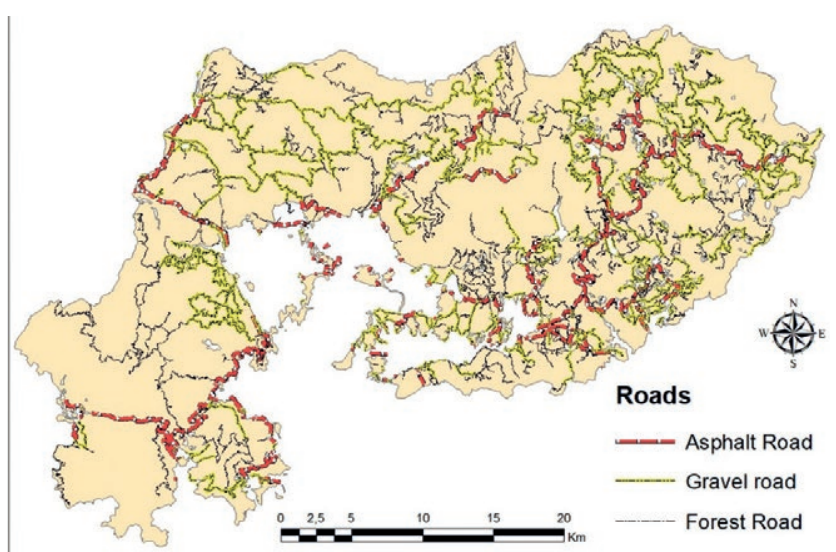

Figure 8. Study area road network

Slika 8. Cestovna mreža u području istraživanja

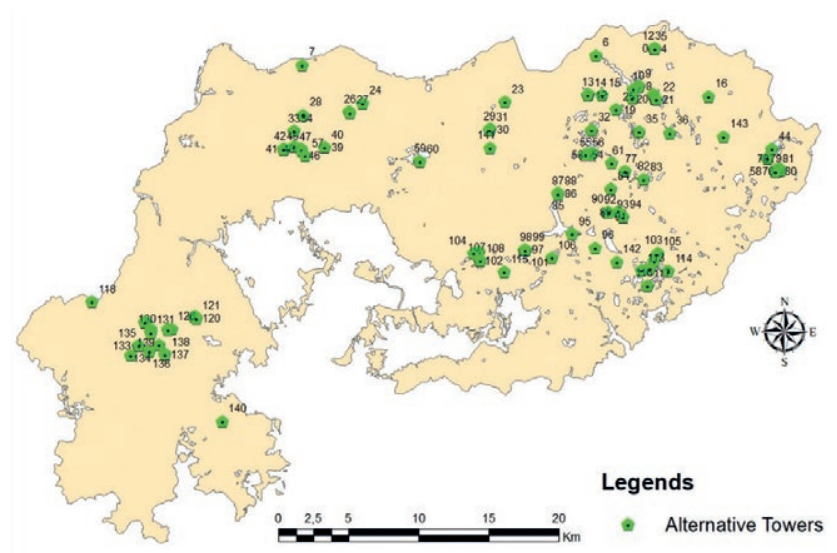

Figure 9. Alternative fire lookout towers

Slika 9. Alternativni tornjevi za nadzor požara

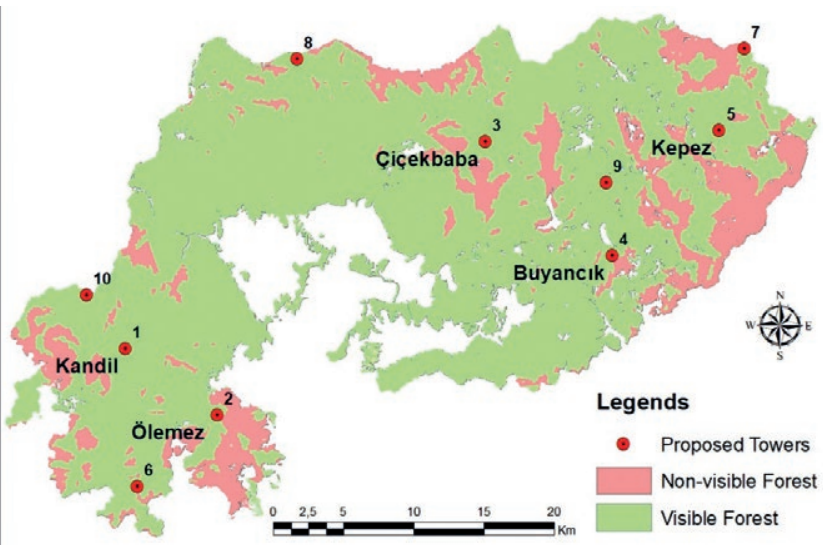

Figure 10. Forest land visibility from the proposed fire lookout towers Slika 10. Vidljivost šumskog područja s predloženih tornjeva za nadzor požara

road (17.14\%). The total area of the buffer polygon (i.e. 100 meters from roadway) generated along the road network was found to be 36188 hectares.
The "Raster Calculator" function was used to generate raster data layer that satisfied other factors (i.e. elevation, ground slope, and ridgelines) within the border of buffer polygon. It was found that there were 144 alternative lookout towers to be evaluated in the visibility analysis (Figure 9). The results indicated that largest percentages of the forest land could be visible by observing the area from 10 fire lookout towers in which five of them were placed on the identical location to the current lookout towers in the study area. These results do validate the existing tower siting process, and also provide support for our GIS-based approach to siting observation towers.

The results indicated that total visible forest lands were increased to $81.47 \%$ by proposing five new fire lookout towers in the study area. Thus, the area visible from the lookout towers increased about $4.35 \%$. Although this may seem like a modest gain in some regards, if such an increase helps to control a single fire, the level of effort in this process has likely been time well spent. The forest lands that are within sight of the lookout towers are shown in Figure 10. In a similar study conducted by Kucuk et al. (2017), a visibility analysis of lookout towers in Turkey was conducted and it was reported that visible areas from lookout towers would be increased from $73 \%$ to $81 \%$ if additional lookout towers were located in the area.

The forest land visible by a single tower was $30.36 \%$, while areas visible by two, three, four, and five towers were $28.78 \%$, $19.89 \%, 2.22 \%$, and $0.22 \%$, respectively. The forest lands visible from various number of fire lookout towers were indicated in Figure 11. It was suggested that forest lands should be observed by at least two fire lookout towers (Çanakçıŏlu, 1993). The forest lands visible by at least two lookout towers was $41.80 \%$ considering the current lookout towers, while visible area increased to $51.12 \%$ after evaluating the lookout towers suggested by the suitability analysis.

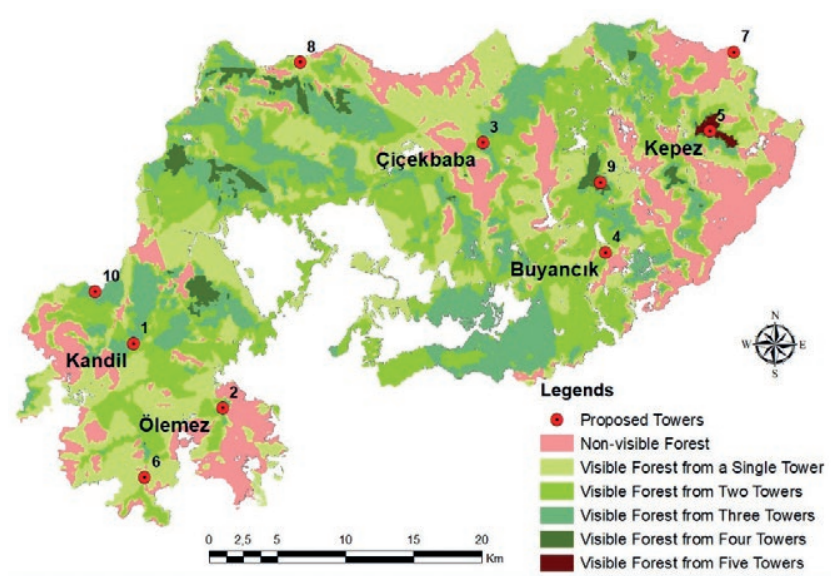

Figure 11. Forest lands visible by one or more lookout towers as suggested by suitability analysis

Slika 11. Šumskog područje vidljivo s jednog ili više tornjeva za nadzor predloženih kroz analizu prikladnosti 


\section{CONCLUSIONS}

\section{ZAKLJUČAK}

This study examined the visibility capabilities of current fire lookout towers in Köyceğiz FED in which forests are sensitive to fire at the first degree. The results indicated that $77.12 \%$ of the forest land was visible from the current lookout towers, however, the rest of the forests (23.88\%) were located in non-visible areas that can be defined as blind spots based on the detection capabilities of the towers. According to the general estimation in mountainous diverse terrain, at least $70 \%$ of the scanned forest lands must be visible from the fire lookout towers for proper monitoring. One might think that $77.12 \%$ visibility rate is satisfactory, but it is vital to monitor most of the forest lands in Köyceğiz since it is located in an ecologically and culturally vibrant region. Therefore, the suitability analysis was conducted to search for appropriate locations for potential new fire lookout towers based on specific factors including distance to roads, elevation, ground slope, and ridgelines. The results revealed that the visible forest lands were increased up to $81.47 \%$ by locating new fire lookout towers in the study area. It can be concluded that GIS-based visibility analysis integrated with suitability analysis can provide decision makers with an effective instrument for developing strategies in fire-fighting planning and fire management activities such as fire prevention, wildlife control, and post fire recovery. Our methods provide a spatially-based template for forest land managers that are interested in investigating whether additional observation towers can be advantageous to fire spotting.

\section{REFERENCES}

\section{LITERATURA}

- Akay, A. E., Sivrikaya F. and Şakar D., 2010: Evaluating the Efficiency of Fire Helicopter Located in Arsuz-Antakya in Fire Fighting Activities. The 1st International Symposium on Turkish \& Japanese Environment and Forestry. 04-06 November. Trabzon, Turkey. pp. 431-445.

- Akay, A. E., Wing, G. M., Sivrikaya, F. and Sakar, D., 2012: A GIS-based decision support system for determining the shortest and safest route to forest fires: a case study in Mediterranean Region of Turkey. Environmental Monitoring and Assessment 184(3):1391-1407.

- Akay, A.E. and Erdoğan, A., 2017: Assessment of Fire Watch Towers by using Visibility Analysis: The Case of Dursunbey, Balıkesir. ISFOR 2017 International Symposium on New Horizons in Forestry, 18-20 October, Isparta, Turkey.

- Akbulak, C. and Özdemir, M., 2008: The Application of the Visibility Analysis for Fire Observation Towers in the Gelibolu Peninsula (NW Turkey) Using GIS. BALWOIS 208, 27-31 May, Ohrid, Republic of Macedonia.

- Bignone, F. and Umakawa, H., 2008: Assessment of ALOS PRISM digital elevation model extraction over Japan. The International Archives of the Photogrammetry, Remote Sensing and Spatial Information Sciences, 37:1135-1138.
- Clark, J., 2015: Exercise 03 - Siting a fire tower in Nebraska. 67 p (2015) https://tr.scribd.com/document/90131023/Exercise03-Siting-a-fire-tower-in-Nebraska\# (Last visit: 19 March 2019)

- Çanakçığlu, H., 1993: Forest Protection. İstanbul University, Faculty of Forestry.

- Davis, K.P. 1959. Forest fire: control and use. McGraw-Hill Book Company Inc., New York.

- Demir, M., Kucukosmanoglu, A., Hasdemir, M., Ozturk, T. and Acar, H.H.,2009: Assessment of forest roads and firebreaks in Turkey. African Journal of Biotechnology 8(18):4553-4561.

- Ertuğrul, M. and Varol, T., 2016: The analysis of large fire incidence in Turkey. International Journal of Sciences: Basic and Applied Research 1(6):1-8.

- GDF, 2012: Annual Management Activity Report, General Directorate of Forestry, April-2013, Ankara.

- GDF, 2016:Köyceğiz Forest Management Directorate, Fire Register Book, Köyceğiz, Muğla.

- Göltaş, M., Demirel, T. and Çağlayan, İ., 2017: Visibility Analysis of Fire Watchtowers Using GIS: A Case Study in Dalaman State Forest Enterprise, European Journal of Forest Engineering 3(2):66-71.

- Gülci, S. and Akay, A.E., 2015: Assessment of ecological passages along road networks within the Mediterranean forest using GIS-based multi criteria evaluation approach. Environmental Monitoring and Assessment, 187(12):779.

- Gülci, N., Serin, H. and Akay, A.E., 2016: Disorders Seen in Fire Lookout Personnel Working in Fire Watch Towers. Kastamonu University Journal of Forestry Faculty 16(2):632-639.

- Harvey, F., 2015: A Primer of GIS, Second Edition: Fundamental Geographic and Cartographic Concepts. The Guilford Press; Second edition. ISBN-10: 9781462522170. 360 p.

- Koikai, J.S., 2008: Utilizing GIS-Based Suitability Modeling to Assess the Physical Potential of Bioethanol Processing Plants in Western Kenya, Saint Mary's University of Minnesota University Central Services Press, Winona, MN.

- Korale, P., Pade, A., Varghese, A. and Joshi, A., 2009: Mapping of forest fire risk zones and identification of suitable sites for fire watch towers using remote sensing and GIS. ISRS Symposium on Advances in Geo-spatial technologies with special emphasis on sustainable rain fed Agriculture, 17-19 September, Nagpur, India.

- Kucuk, O., Topaloglu, O., Altunel, A.O. and Cetin, M., 2017: Visibilty analysis fire lookout towers in the Boyabat state forest enterprise in Turkey, Environmental Monitoring and Assessment, 189(2017):329.

- Mascaraque, S.A., Rodríguez, F.G. and Hernández, P.E., 2007: Optimización de la ubicación de puestos de vigilancia de incendios forestales. Proceedings of the International Wildland Fire Conference, May 13-17, Palacio de exposiciones congresos, Seville, Spain.

- Millan-Garcia, L., Sanchez-Perez, G., Nakano, M., ToscanoMedina, K., Perez-Meana, H. and Rojas-Cardenas, L., 2012: An early fire detection algorithm using IP cameras. Sensors 12(5):5670-5686.

- Pompa-García, M., Solís-Moreno, R., RodríguezTéllez, E., Pinedo-Álvarez, A., Avila-Flores, D., Hernández-Díaz, C. and 
Velasco-Bautista, E., 2010: Viewshed analysis for improving the effectiveness of watchtowers, in the north of Mexico. Open Forest Science Journal, 3:17-22.

- Quinta-Nova, L. Fernandez, P. and Nuno, P., 2017: GIS-Based Suitability Model for Assessment of Forest Biomass Energy Potential in a Region of Portugal, World Multidisciplinary Earth Sciences Symposium (WMESS 2017), IOP Conf. Series: Earth and Environmental Science, Prague.

- Singh, Y., Sharma, M.P., Sharma, S.D., Prawasi, R., Yadav, K. and Hooda, R.S., 2014: Application of GIS technique to select suitable sites for erecting watch towers in forest areas of mountainous tract. Int. J. Computer Technology and Applications (2):462-468.
- Sivrikaya, F., Saglam, B., Akay, A.E. and Bozali, N., 2014: Evaluation of forest fire risk with GIS. Polish Journal of Environmental Studies 23(1):17-194.

- Trisakti, B. and Julzarika, A., 2011: DEM Generation from Stereo Alos Prism and Its Quality Improvement. International Journal of Remote Sensing and Earth Sciences (IJReSES), 8:4148.

- Vipin, V., 2012: Image processing based forest fire detection. Emerging Technology and Advanced Engineering 2(2):87-95.

- Yuan, C., Zhang, Y. and Liu, Z., 2015: A survey on technologies for automatic forest fire monitoring, detection, and fighting using unmanned aerial vehicles and remote sensing techniques. Canadian Journal of Forest Research 45(7):783-792.

\section{SAŽETAK}

Učinkovito suzbijanje šumskih požara uključuje trenutno uzbunjivanje protupožarnih timova u slučaju požara kako bi mogli na vrijeme stići na mjesto požara. Najučinkovitiji način ranog uočavanja šumskog požara je nadzor šumskih područja s tornjeva za nadzor požara. Tornjevi bi trebali biti sustavno smješteni na način da osoblje za nadzor može nadzirati najveću moguću površinu šume, osobito u ugroženijim šumskim predjelima. U ovom su istraživanju procijenjene mogućnosti promatranja tornjeva za nadzor smještenih u šumariji Köyceğiz, u gradu Muğla u Turskoj pomoću analize vidljivosti i prikladnosti potpomognutom Geografskim informacijskim sustavom (GIS). Rezultati analize vidljivosti pokazali su da je 77,12 \% šumskog područja vidljivo sa sadašnjih tornjeva. Kako bi se povećao udio vidljivoga šumskog područja, lokacije dodatnih tornjeva za nadzor procijenjene su pomoću analize prostorne vidljivosti i prikladnosti u kojoj su lokacije tornjeva ispitane razmatrajući specifične kriterije (npr. udaljenost od cesta, visina, nagib terena, topografske karakteristike). Rezultati analize prikladnosti identificirali su pet novih tornjeva uz sadašnje tornjeve na promatranome području. Rezultati su pokazali da bi se dodavanjem novih tornjeva vidljiva šumska površina povećala na $81,47 \%$, što je povećanje od gotovo $4,35 \%$. Uz to, analiza prikladnosti pokazala je da bi preko polovice šume bilo vidljivo s najmanje dva tornja kada bi se dodalo ovih pet tornjeva. Metoda potpomognuta GIS-om razvijena u ovome istraživanju može pomoći upraviteljima za zaštitu od požara da odrede optimalne lokacije za tornjeve za nadzor požara u svrhu učinkovitih protupožarnih aktivnosti.

KLJUČNE RIJEČI: šumski požar, tornjevi za nadzor požara, analiza vidljivosti, analiza prikladnosti, Köyceğiz 